\title{
RESEARCH OF NATURAL WOOD COMBUSTION AND CHARRING PROCESSES
}

\author{
Romualdas Mačiulaitis ${ }^{1}$, Andrejus Jefimovas ${ }^{2}$, Povilas Zdanevičius ${ }^{3}$ \\ Department of Building Materials, Vilnius Gediminas Technical University, \\ Sauletekio al. 11, LT-10223 Vilnius, Lithuania \\ E-mails: ${ }^{1}$ romualdas.maciulaitis@vgtu.lt; ${ }^{2}$ andrejus.jefimovas@dok.vgtu.lt (corresponding author); \\ povilas.zdanevicius@vgtu.lt \\ Received 04 Jan. 2012; accepted 20 Jun. 2012
}

\begin{abstract}
Wood is a material widely used for construction purposes and - in some cases - it is the main element of building structures. In comparison with other materials, wood has a number of advantages, such as lightness, strength, resistance to impacts and vibration, simplicity in terms of processing and etc. However, one of the largest drawbacks of wood is flammability. Charring of wooden structures is the most apparent feature of combustion in case of fire in wooden buildings or buildings made of wooden structures. This property is important in identifying causes of fire; therefore it is necessary to relate charring of wooden structures with certain significant effects of fire, such as its duration or temperature. The article addresses the wood characteristics that impact on combustion and charring. It describes test methods and properties of wood samples under research. Research of charring rate of natural softwood and hardwood as a function of heating time, and regressive analysis of data were carried out. Empiric equations were derived. The calorific value of carbon residue resulting in different temperatures was determined in accordance with LST EN ISO 1716. Thermographic research of oak and pine wood was carried out in different gaseous environments. The research results were summarised in the form of conclusions.
\end{abstract}

Keywords: timber, wood characteristics, combustion, charring, calorimetric bomb, calorific value, thermography.

\section{Introduction}

Wood is a material used in many areas of engineering and technology. It is used for manufacturing of building structures and items, furniture and its parts, chipboards, plywood, flitch, paper, cardboard and etc. In chemical industry, it is a suitable raw material for production of a perfect absorbent charcoal as well as products of its pyrolysis hydrocarbons, which are used to make gaseous fuel; and in case of further processing, it can be used for synthesis of organic solvents and even monomers. Wood is a fibrous material with a directional structure of capillaries and pores clearly developed in the vertical direction of the tree growth (anisotropy of properties), which is fed with water and fertilizers (especially mineral salts) taken from soil through tree roots, and which with the help of chlorophyll ensures photosynthesis as well as uptake of nitrogen from air. Such is the abstract summarised picture of wood synthesis (Jefimovas 2011).

\section{Wood Characteristics}

Wood is a unique anisotropic porous material of vegetable origin, where the volume of pores takes 50$75 \%$ of the wood volume. It has a number of advantages in comparison with other materials: it is solid and may bear high loads. At the same time it is light, has low heat conductivity, is easy to process and etc. However, there are some important drawbacks of wood, such as absorp- tion of large quantities of water, decay, deformation under the influence of humidity, and most importantly flammability (Šniuolis 2004).

The main mass of completely dry wood (about 99\%) consists of organic substances. In addition to organic substances, wood contains some minerals (salts), which turn to ash after wood is burnt. Irrespective of tree species, completely dry wood has $49-50 \%$ of carbon, $43-$ $44 \%$ of oxygen, about $6 \%$ of hydrogen and $0.1-0.3 \%$ of nitrogen. Carbon, hydrogen and oxygen form complex organic substances - cellulose, hemicellulose, lignin and the so-called extractive substances (resins, gums, fat, tannides, pectins, etc.) (Jakimavičius 2003).

Peculiarities of Thermal Decomposition and Combustion of Wood

Depending on botanic origin, growing conditions, species and the age of wood, the ratio of wood components is approximately as follows: $50 \%$ of cellulose, $25 \%$ of hemicellulose, $25 \%$ of lignin. Wood composing substances have a varied structure and different thermal resistance (Drysdale 1998).

Referring to the data of thermographic research obtained by various authors, the thermal decomposition of wood components takes place at different temperatures; however, different combustion media and wood species are also used. As described by Roberts (1970), decomposition (under vacuum conditions) takes place at the fol- 
lowing temperatures: hemicellulose $-200-260{ }^{\circ} \mathrm{C}$; cellulose $-240-350{ }^{\circ} \mathrm{C}$; lignin $-280-500{ }^{\circ} \mathrm{C}$.

Hemicellulose and cellulose have a tendency of thermal decomposition, whereas lignin is resistant to thermal decomposition and its pyrolysis results in a char layer. Thermal decomposition of wood can take place in case of free and partial supply of atmospheric oxygen. It can also take place in case of oxygen shortage in the atmosphere. Considering that a char layer results on the surface of wood, it should be said that wood combustion is a particular process. During combustion, this layer forms a tight shell, which impedes heat entrance into deeper undecomposed layers of material and blocks free release of volatile products into the atmosphere in the course of thermal decomposition. Such behaviour at high temperatures restricts fire spreading for a certain period of time. However, it is important that thermal decomposition continues under the charred layer of wood, which may be very dangerous as oxygen amounts to $43-44 \%$ in the chemical composition of wood (Drysdale 1998). The products of thermal decomposition can instigate smouldering. Shortly, formation of gas during smouldering can cause the pressure to increase so high that char layer can break resulting in flaming up (Jaskolowski 2001).

Usually, two methods to model pyrolysis of wood (biomass) are used (Turner et al. 2010).

The first method is based on prediction taking into account behaviour of wood, which depends on its main components according to the equation (Koufopanos et al. 1989): wood $=\%$ cellulose $+\%$ hemicellulose $+\%$ lignin, where $(\%)$ is the amount of wood components.

The second method called the "Lumped Parameter Approach" is based on classification of products that form during decomposition of wood (biomass), having in mind that there is one homogenous element consisting of dense products (resins), uncondensed products (gas) and solid bodies (char). As a basis, the model uses three parallel initial reactions when wood decomposes into char, resin and gas, however, there are also secondary reactions taking place when resin decomposes into char and gas (Turner et al. 2010). It should be emphasized that both methods, in our opinion, only supplement each other without being inconsistent.

Combustion as a phenomenon can take various forms, however in the end they all come down to a chemical reaction between a flammable substance and air. Proper use of this reaction results in numerous benefits (power or heat sources), but if uncontrolled, it can cause both serious material damage and human death (Drysdale 1998). Fire is a complex phenomenon: its course and effects depend on many interrelated factors. In case of fire, the most noticeable feature in wooden buildings or buildings made of wooden structures is charring of wooden items. This feature is important in identifying the cause of fire, therefore, it is necessary to relate charring of wooden items and structures with particular significant effects of fire, such as its duration or temperature (Lipinskas 2006). Wood is a complex material; its pyrolysis and combustion is influenced by various characteristics, in addition to that, the dynamics of fire development is determined by various factors, and all of the listed circumstances make it difficult to determine combustion duration and temperature of wood.

\section{Thermographic Analysis}

The thermographic analysis is used to study mechanism and kinetics of thermal decomposition and combustion of natural wood unimpregnated with fire retardants and its products (Fu et al. 2011). The results of thermographic research carried out by other authors suggest that decomposition of materials due to combustion is affected by substance (tree) species (Bednarek et al. 2009) and the temperature rise rate (Hagen et al. 2009; Otero et al. 2007; Yorulmaz, Atimtay 2009; Helsen et al. 1999) as well as the environment (oxidizing, reducing gas), in which the substance is being studied (Fu et al. 2011; Zhaosheng et al. 2009) simulating conditions, which may occur during a fire.

\section{Peculiarities of Charring}

Under fire conditions, wood experiences pyrolysis (thermal destruction) (Fig. 1). Pyrolytic gas typically flames up as soon as it rises up to the surface of charred wood. Further combustion and mechanical degradation of char finally destroys or splits off the outer layer of char. The charring rate is in fact linearly dependent on time. The temperature of char layer formation averages $300{ }^{\circ} \mathrm{C}$ (Lipinskas, Mačiulaitis 2005).

During transformation of wood into char and combustible gas, products of pyrolysis are substantially dependent on wood density. Dependence of the charring rate on the unprotected wood density is also emphasized in Eurocode 5 (LST EN 1995-1-2:2005). The standard assigns the uniform charring rate for softwood with the density of $\geq 290 \mathrm{~kg} / \mathrm{m}^{3}$ and two ranges for hardwood with the density of $290 \mathrm{~kg} / \mathrm{m}^{3}$ and $\geq 450 \mathrm{~kg} / \mathrm{m}^{3}$.

Charring rate is influenced by wood moisture, surface orientation, air movement, thermal load, gaps and etc. Heavy-timber or similar wood that has no gaps or joints will char at similar rates to those found in fire-resistance furnace tests - roughly $0.5-0.8 \mathrm{~mm} / \mathrm{min}$. Much higher charring rates apply to floors and any other wood members where charring is affected by the presence of gaps or joints. Laboratory tests show a typical charring rate for floorboards of $1.5 \mathrm{~mm} / \mathrm{min}$, but under numerous conditions the values are much larger. Even small gaps between boards, if they are not blocked or otherwise protected, raise the charthrough rate to $3-8 \mathrm{~mm} / \mathrm{min}$ (Babrauskas 2005).

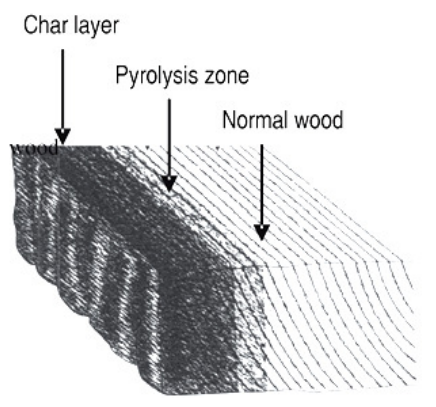

Fig. 1. Wood destruction scheme (Lipinskas, Mačiulaitis 2005) 
Charring of wood is closely related to the combustion characteristics of wood components - hemicellulose, cellulose and lignin - which influence formation of char. The majority of char is formed during combustion of lignin (Drysdale 1998).

Charring of wood is also dependent on the heat load applied on the structural surface and change in the value of heat load depending on the length of thermal exposure (Taubkin 1999). In our opinion, based on the data provided in Fig. 2, it can be interpreted that the uniform charring depth may be obtained by exposing wood to different temperatures for various periods of time. However, the uniform charring depth can also result from wood exposure to different conditions of pyrolysis. It is therefore not appropriate to estimate combustion duration, which is used for identification of the fire source, only by charring depth. In Lithuania, in order to determine the charring time of wooden structures, the charring depth and electrical resistance of char are measured. The charring time of wooden structures is calculated according to the measured values of depth and electrical resistance and using the dependencies (Lipinskas 2006) as well as taking into account the thickness and moisture of the original wooden structure. According to this time, the focus of fire is forecasted. However, this measuring method is not widespread, as it requires special equipment.

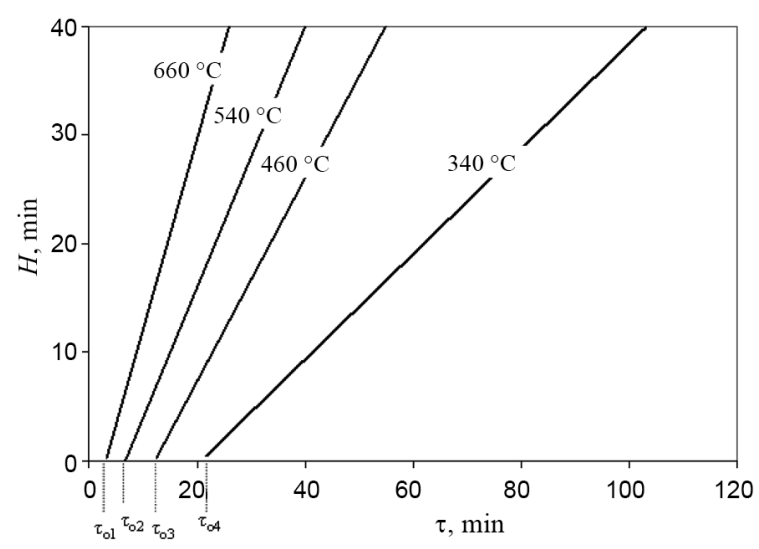

Fig. 2. The dependence between wood charring depth $\mathrm{H}$ and the combustion time $\tau$ at medium temperatures (Taubkin 1999)

The aim of the work is to investigate how the calorific value of char resulting in wood of different species at different temperature changes and what effect conditions of gaseous environment have on peculiarities of wood combustion using the widespread method of a calorimetric bomb.

\section{Materials tested and testing methods}

\subsection{Tested materials and their characteristics}

For experiments, softwood (pine, fir) and hardwood (aspen, oak) was used. Before tests, wood was conditioned according to the requirements of LST EN 13238:2010. The following average values of wood density were determined: pine $-545 \mathrm{~kg} / \mathrm{m}^{3}$, fir $-513 \mathrm{~kg} / \mathrm{m}^{3}$, aspen $506 \mathrm{~kg} / \mathrm{m}^{3}$, oak $-654 \mathrm{~kg} / \mathrm{m}^{3}$. The moisture content in the samples of oak was $12-15 \%$, aspen $-12-14 \%$, fir $-11-$
$12 \%$, pine $-11-13 \%$, the moisture content was determined using a moister meter "HPM 2000".

\subsection{The special one-side heating equipment}

To identify charring peculiarities in wood of different species at different temperatures, special one-side heating equipment was used (Lukošius 2004; Lipinskas, Mačiulaitis 2005). This equipment ensures the simulated one-side heating of the test sample up to $950{ }^{\circ} \mathrm{C}$. The equipment consists of one-side heating device, thermocontroller, instrumentation and equipment for recording the readings (Fig. 3).



Fig. 3. The principal scheme of the one-side heating equipment that has been used for one side heating tests: 1 - one-side heating apparatus; 2 - fragment of the tested structure; 3 temperature and heat flow measuring equipment; 4 - Eurotherm 401 recorder; 5 - TR-5 controller for regulation of temperature in the heating chamber

The principle of the experiment is to heat the sample on one side based on dependency of temperature depending on time specified in and regulated by LST EN 13631:2000.

For the purposes of testing, the above-described equipment ensured the chosen heat load. The heat load on the structural surface and change in the load value depending on the heating mode undoubtedly have an influence on temperature distribution over the cross-section of the structure.

The chosen basic heat load was regulated by the standard dependency of temperature depending on time (Fig. 4), which simulated the post-flashover stage. Fire resistance tests of structures were carried out in various countries worldwide using the mentioned dependency (in case of the chosen dependency between temperature and time, in the beginning the temperature increases at about $100{ }^{\circ} \mathrm{C} / \mathrm{min}$ ).

The mathematical expression of the standard temperature-time curve (Fig. 4) is as follows (1):

$$
T=345 \lg (8 t+1)+20,
$$

where: $T$ - average temperature in the heating chamber, ${ }^{\circ} \mathrm{C} ; t$ - test duration, min.

Different rate of the temperature change in the heating chamber is important in several respects. The high temperature reached at high rate simulates the environmental conditions, which are the most unfavourable for the material being tested, when a continuous process of heat propagation influencing physical and chemical transformations in the material begins. 


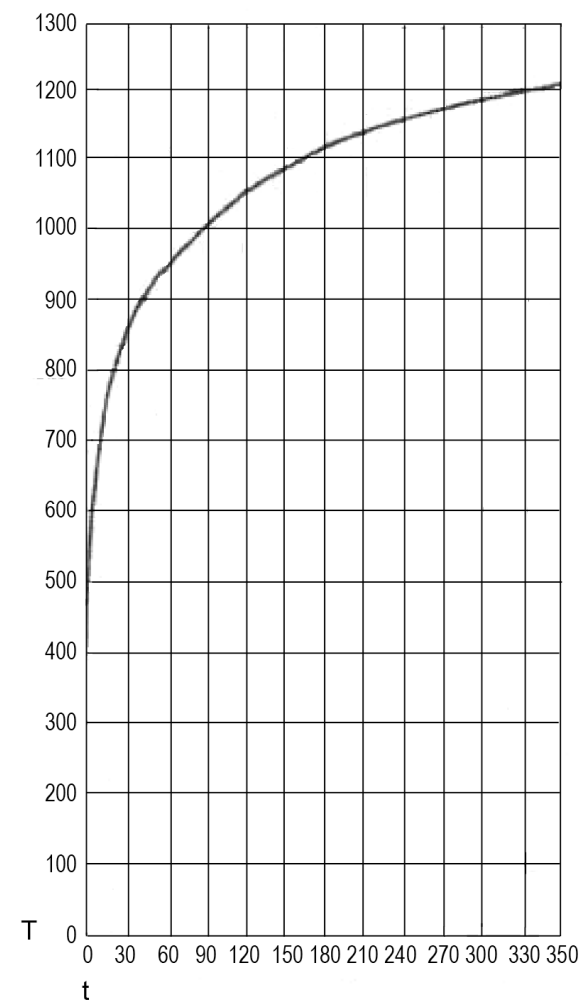

Fig. 4. Temperature and time curve

The height and width of the wood samples was $210 \mathrm{~mm}$ and $150 \mathrm{~mm}$ respectively, the thickness varied from $47 \mathrm{~mm}$ to $59 \mathrm{~mm}$ (Fig. 5).

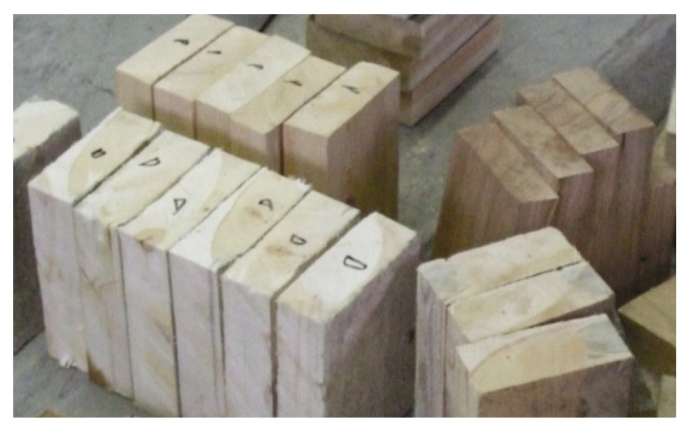

Fig. 5. Wood samples used for the research

Using the described equipment, the wood samples were exposed to heating for a specific pre-set period of time $\tau$, $\min (5,10,20,30$ and 45$)$. During this period, the average heating temperatures shown in Table 1 were reached, after this period the sample was removed from the chamber followed by its extinguishing with a fire blanket.

Table 1. The average reached temperature in the heating chamber depending on time

\begin{tabular}{c|c}
\hline $\begin{array}{c}\text { Heating time, } \\
\min \end{array}$ & $\begin{array}{c}\text { Reached average heating temperature, } \\
{ }^{\circ} \mathrm{C}\end{array}$ \\
\hline 5 & 580 \\
\hline 10 & 680 \\
\hline 20 & 780 \\
\hline 30 & 840 \\
\hline 45 & 900 \\
\hline
\end{tabular}



Fig. 6. Measurement of charring depth

After the sample cooled down, the charring depth $\mathrm{H}, \mathrm{mm}$ of wood under research was measured using sliding callipers. The measurements of charring depth were taken as shown in Fig. 6. The depth was measured in the surface part of the sample and the measurement result was the average of at least 3 measurements. Three samples were heated for each specified period of time. Once the charring depth was measured, the charring rate of wood $\beta, \mathrm{mm} / \mathrm{min}$ was calculated using the following Eq. (2):

$$
\beta=\frac{H}{\tau},
$$

where: $\beta$ - charring rate of wood, $\mathrm{mm} / \mathrm{min} ; \tau$ - combustion time, min, $H$ - charring depth, $\mathrm{mm}$.

The char formed during these tests was used for further research. For that purpose, the layer of resulting char of up to $5 \mathrm{~mm}$ thick was scraped off with a knife.

\subsection{Calorimetric bomb method}

Research of the resulting char was followed up by the test method described in LST EN ISO 1716:2010 Reaction to fire tests for products - Determination of the gross heat of combustion (calorific value), which is applied to determine reaction to fire classes $\mathrm{A} 1$ and $\mathrm{A} 2$ according to LST EN 13501-1:2007. By performing this test, the gross calorific value and net calorific value can be determined. The said values are also known as the higher and lower heating values respectively. The gross calorific value (or higher heating value) is defined as the amount of heat released by combusting the product and the entire water component is in liquid state at the end of combustion. The net calorific value (or lower heating value) is defined as the amount of heat released by combusting and the entire water component is in vapour state at the end of combustion. During research the gross calorific potential for char was determined, which hereinafter is referred to as the calorific value and marked as PCS. The essence of this test is to determine how much heat is released by completely burnt wood or charcoal. For that purpose, special equipment (Fig. 7) was used. This equipment consists of a stirrer, thermometer, calorimeter vessel, casing and a combustion chamber (calorimetric bomb) (Fig. 8). 


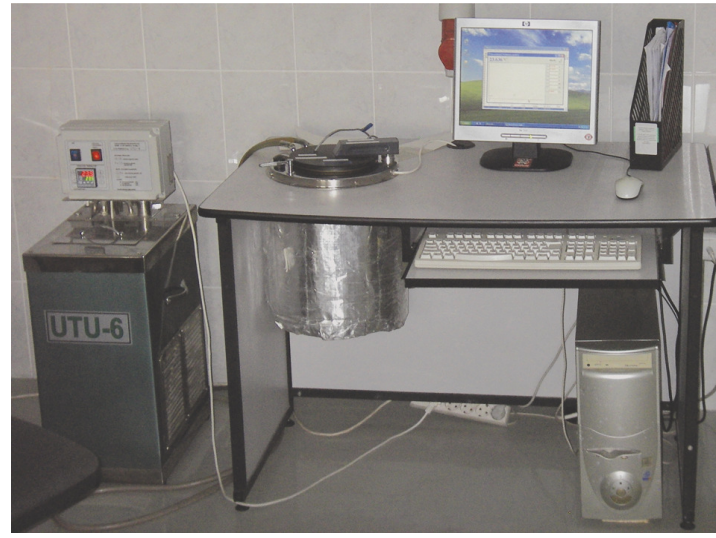

Fig. 7. Testing equipment



Fig. 8. Calorimeter parts: 1 - mixer for uniform mixing of water; 2 - jacket cover; 3 - fuse cables; 4 - water thermometer; 5 calorimeter vessel; 6 - water in the jacket; 7 - calorimetric bomb; 8 - fuse wire; 9 - crucible containing the sample

During testing, the mixer is rotated at a constant rate. In order to avoid heat transfer from and to the calorimeter, the driving axle of the mixer is equipped with a thermally insulated element located in the gasket between the jacket and jacket cover. Magnetic mixing device can also be used. When the temperature rise in the calorimeter vessel does not exceed $0.01{ }^{\circ} \mathrm{C}$ per 10 minutes, the sample is ignited and the changes in temperature are recorded against the time scale. Standard temperature changes against the time scale and the characteristic points are shown in Fig. 9.

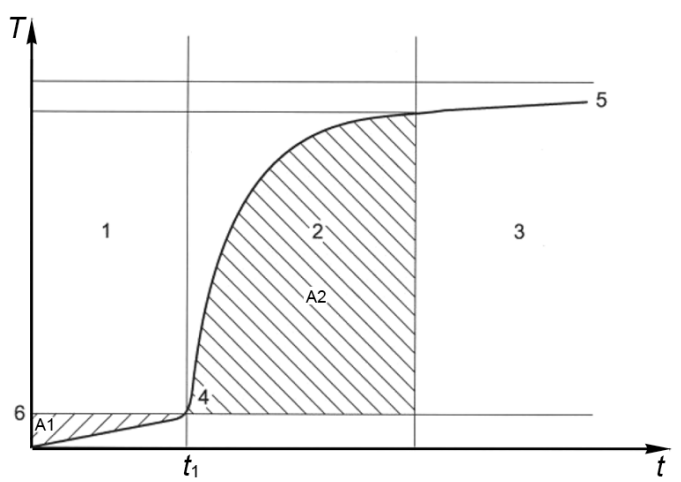

Fig. 9. Temperature/time curve: $T$ - temperature; $t$ - time; 1 preliminary period; 2 - main period; 3 - final period; 4 - ignition; 5 -temperature of the jacket; 6 - time when the temperature of the water in the crucible vessel is equal to the temperature of the jacket
The course of research was as follows: any dirt was brushed off from the sample of charred wood and up to $5 \mathrm{~mm}$ of the top char layer was scraped with a knife from different points of the sample. Taken char was ground with a pestle in the mortar. The ground char was placed into the open vessel. The vessel with the char was conditioned to the constant mass in a laboratory furnace at the temperature of approx. $60^{\circ} \mathrm{C}$.

$0.5-1.0 \mathrm{~g}$ of crushed charcoal - which was conditioned to the constant mass - was placed to the glassy crucible (dimensions: diameter of $25 \mathrm{~mm}$, height of $19 \mathrm{~mm}$, and wall thickness of $1.5 \mathrm{~mm}$ ). Specimens were weighed using a high accuracy weighing-scale to the precision of $+/-$ $0.0001 \mathrm{~g}$. The crucible was placed into the calorimeter bomb. A fuse wire was attached to the calorimeter bomb electrodes $(10 \mathrm{~cm}$ length, $0.0055 \mathrm{~g}$ weight $)$ in such manner that the coil formed in the centre of the bomb contacted the specimen contained in the crucible. The calorimeter bomb was placed in its steel body and screwed tightly. Then the calorimeter bomb vessel was filled with pressurised oxygen $(99.5 \%$ purity) until the pressure of $3.0-3.5 \mathrm{MPa}$ was reached. Simultaneously, the calorimeter vessel was filled with distilled water until the weight of $3.4 \mathrm{~kg}$. The calorimeter bomb was placed into the water of stable temperature in such manner that the top of the bomb was slightly submerged in the water. Fuse cables were attached to the electrodes and the jacket cover was closed. All testing equipment was controlled via the computer. Using a software application, the necessary data are entered into the computer: specimen weight, including fuse wire weight.

Once the test was completed, the jacket cover was opened, the calorimeter bomb was removed and dried, and the test results and temperature curve were recorded on the computer screen. The calorific value was calculated by the software installed in the computer.

Three tests were performed with each sample of resulting char. Each three samples were heated for the same period of time, therefore the arithmetic average of nine samples was considered to be the calorific value of char.

The calorific value of wood (oak, aspen, pine and fir) dried to the constant mass in a laboratory drying chamber at the temperature of $60{ }^{\circ} \mathrm{C}$ was also determined. In that case, the tests were conducted with wood chip tablets and the calorific value was accounted for as the arithmetic average of values obtained during three tests.

\subsection{Termogravimetric analysis}

The thermografic analysis was performed using the thermogravimetric analyser "Linseis STA PT-1600". The analysis was carried out under temperatures ranging from $25^{\circ} \mathrm{C}$ to $1000^{\circ} \mathrm{C}$. The temperature rise rate was $10^{\circ} \mathrm{C} / \mathrm{min}$. The analysis was performed in gaseous environments of nitrogen and ambient air. The flow of nitrogen and air was $0.15 \mathrm{l} / \mathrm{min}$. Pieces of wood (oak and pine) weighing 9.36-10.17 mg were used for testing.

\section{Research results and discussion}

The results of charring research, which was carried out with different species of wood using one-side heating chamber, are shown in Figs 10 and 11. 


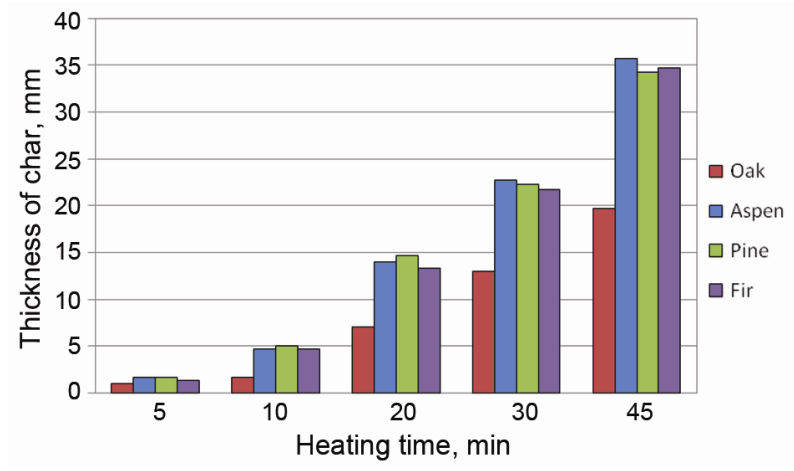

Fig. 10. Average thickness of char forming during heating of wood samples

Fig. 10 reflects the thickness of char that forms during heating of wood (oak, aspen, pine and fir) in a chamber for a different period of time (the mean temperature values reached during this period of time are presented in Table 1).

Irrespective of heating time, the smallest thickness of char resulted in oak: in 5 minutes of heating, the char layer reached $1.0 \mathrm{~mm}$ in thickness; while after 45 minutes $-19.7 \mathrm{~mm}$. Heating of oak resulted in the thickness of char that was 1.7-2.8 times less than that of aspen (after $5 \mathrm{~min}-1.7 \mathrm{~mm}$, after $10 \mathrm{~min}-35.7 \mathrm{~mm}$ ). The difference in the resulting char thickness can be explained by different density of wood as the average density of oak used for testing was $654 \mathrm{~kg} / \mathrm{m}^{3}$ and that of aspen $-506 \mathrm{~kg} / \mathrm{m}^{3}$.

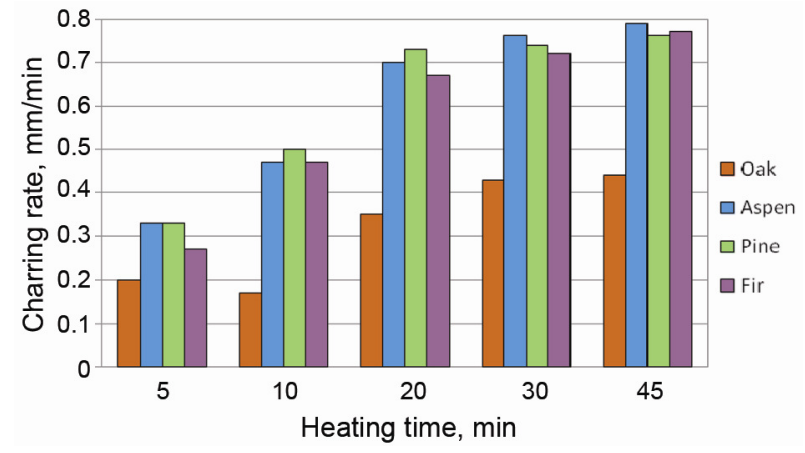

Fig. 11. Average values of charring rates for wood samples

The values of the charring rate for the wood samples are presented in Fig. 11. The lowest charring rate was characteristic to oak samples. The exception was oak samples where after 10 minutes of heating the charring rate was slightly lower than that after 5 minutes, which can be explained by greater variation of density. If heated for 20 minutes, the charring rate significantly increased and reached $0.35 \mathrm{~mm} / \mathrm{min}$. If heated for 30 and 45 minutes, the difference in the charring rate was as little as 0.1 ; after $30 \mathrm{~min}-0.43 \mathrm{~mm} / \mathrm{min}$ and after $45 \mathrm{~min}-$ $0.44 \mathrm{~mm} / \mathrm{min}$.

In comparison to oak, the charring rate of aspen samples as well as those of pine and fir were higher. If heated for 5 minutes, the charring rate of aspen and pine was $0.33 \mathrm{~mm} / \mathrm{min}$ and that of fir was $0.27 \mathrm{~mm} / \mathrm{min}$. After 10 minutes of heating, differently than in case of oak wood
$(0.17 \mathrm{~mm} / \mathrm{min})$, the charring rate of aspen $(0.47 \mathrm{~mm} / \mathrm{min})$, fir $(0.14 \mathrm{~mm} / \mathrm{min})$ and pine $(0.50 \mathrm{~mm} / \mathrm{min})$ wood increased evidently. If heated for 20,30 and 45 minutes, the difference in the charring rates were not that big: aspen -0.70 $0.76-0.79 \mathrm{~mm} / \mathrm{min}$, pine $-0.73-0.74-0.76 \mathrm{~mm} / \mathrm{min}$, fir $0.67-0.72-0.77 \mathrm{~mm} / \mathrm{min}$, respectively.

The average charring rate of oak was $0.32 \mathrm{~mm} / \mathrm{min}$, fir $-0.58 \mathrm{~mm} / \mathrm{min}$, pine $-0.60 \mathrm{~mm} / \mathrm{min}$, aspen $0.61 \mathrm{~mm} / \mathrm{min}$. The average charring rate of aspen was $48 \%$ higher than that of oak.

After 45 minutes of heating, the charring rate of oak was $0.44 \mathrm{~mm} / \mathrm{min}$, aspen $-0.79 \mathrm{~mm} / \mathrm{min}$, fir $0.77 \mathrm{~mm} / \mathrm{min}$, pine $-0.76 \mathrm{~mm} / \mathrm{min}$. The values of the charring rates for hardwood provided in Eurocode 5 (LST EN 1995-1-2:2005) were $0.50-0.55 \mathrm{~mm} / \mathrm{min}$, for soft wood $-0.65-0.80 \mathrm{~mm} / \mathrm{min}$. Thus, not all values of the charring rate obtained during tests matched the ones provided in the Eurocode 5 (LST EN 1995-1-2:2005).



Fig. 12. Average values of predicted charring rates for wood samples

The regression analysis of the charring rate for different species of wood was made, equations (3)-(6) were obtained, the predicted values of the charring rate calculated using the equations (3)-(6) are presented in Fig. 12. For derivation of equations, two parameters were chosen - charring duration and charring rate. The equations were derived using all experimental data of the charring process obtained for different species of wood.

The regression analysis resulted in the highest value of the correlation coefficient $\mathrm{R}=0.9597$, which was obtained in predicting the charring rate of aspen, fir $\mathrm{R}=0.9515$, oak $-\mathrm{R}=0.9424$ and pine $-\mathrm{R}=0.9240$, which was the lowest value.

To predict the charring rate of different species of wood (oak, aspen, pine and fir), the following equations (3)-(6) can be used:

Oak: $\mathrm{Y}_{\mathrm{a}}=(0.1458+0.0058 \mathrm{X})^{*}\left(\mathrm{Y}_{\mathrm{a}} \leq 0.3174\right)+$ $(0.3510+0.0021 \mathrm{X})^{* *}\left(\mathrm{Y}_{\mathrm{a}}>0.3174\right)$;

Aspen: $\mathrm{Y}_{\mathrm{d}}=(0.2000+0.0267 \mathrm{X}) *\left(\mathrm{Y}_{\mathrm{d}} \leq 0.6097\right)+$ $(0.6352+0.0036 \mathrm{X})^{* *}\left(\mathrm{Y}_{\mathrm{d}}>0.6097\right)$;

Pine: $\mathrm{Y}_{\mathrm{p}}=(0.1667+0.0333 \mathrm{X}) *\left(\mathrm{Y}_{\mathrm{p}} \leq 0.6148\right)+$

$(0.7092+0.0012 \mathrm{X})^{* *}\left(\mathrm{Y}_{\mathrm{p}}>0.6148\right)$;

Fir: $\mathrm{Y}_{\mathrm{e}}=(0.0667+0.04 \mathrm{X}) *\left(\mathrm{Y}_{\mathrm{e}} \leq 0.5785\right)+$

$(0.5908+0,0041 \mathrm{X})^{* *}\left(\mathrm{Y}_{\mathrm{e}}>0.5785\right)$, 
where: ${ }^{*}$ - the equation is applicable when the charring rate is $\leq$ than the indicated specific value. From Fig. 12 it can be seen that this equation will be applicable when the charring duration is $5-10 \mathrm{~min} ; * *$ - the equation is applicable when the charring rate is $>$ than the indicated specific value. From Fig. 12 it can be seen that this equation will be applicable when the charring duration is $20-45 \mathrm{~min}$.

Dependency of the calorific value of char resulting from different species of wood depending on the heating time is provided in Fig. 13.

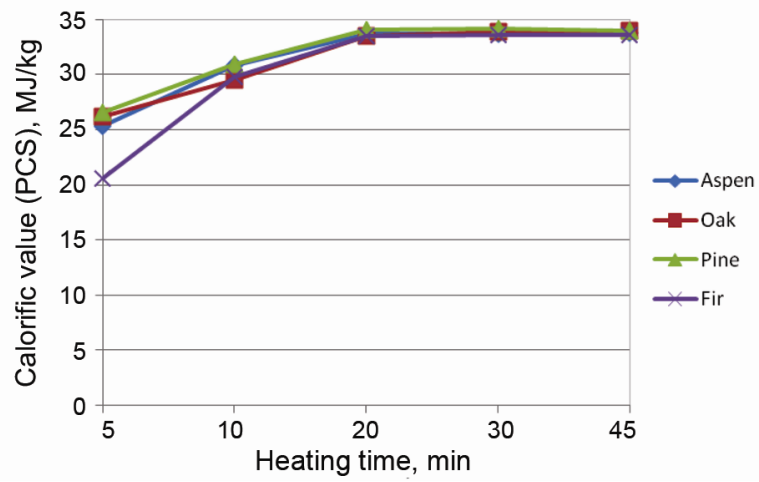

Fig. 13. Average dependency of calorific value of char resulting from different species of wood depending on heating time

The calorific value of char resulting from oak wood reached $26.1 \mathrm{MJ} / \mathrm{kg}$ after 5 minutes of heating. After 10 minutes of heating, the calorific value increased up to $29.5 \mathrm{MJ} / \mathrm{kg}$; after 20,30 and 45 minutes of heating, the calorific values of char were more or less the same; after $20 \mathrm{~min}-33.5 \mathrm{MJ} / \mathrm{kg}$, after $30 \mathrm{~min}-33.9 \mathrm{MJ} / \mathrm{kg}$, after $45 \mathrm{~min}-34.0 \mathrm{MJ} / \mathrm{kg}$. The maximum calorific value of char was reached after 45 minutes of heating. Even after 5 minutes of heating, the calorific value of char was higher than the value of the wood itself, the determined calorific value of dry oak was $18.9 \mathrm{MJ} / \mathrm{kg}$.

The calorific value of char resulting from aspen wood was $25.3 \mathrm{MJ} / \mathrm{kg}$ after 5 minutes of heating; after $10 \mathrm{~min}-30.8 \mathrm{MJ} / \mathrm{kg}$; after 20,30 and 45 minutes of heating, the calorific values were similar $-33.7 \mathrm{MJ} / \mathrm{kg}$, $33.7 \mathrm{MJ} / \mathrm{kg}$ and $33.8 \mathrm{MJ} / \mathrm{kg}$, respectively. The calorific value of dry aspen wood was $18.7 \mathrm{MJ} / \mathrm{kg}$.

The calorific value of char resulting from pine wood was $26.5 \mathrm{MJ} / \mathrm{kg}$ after 5 minutes of heating; after $10 \mathrm{~min}-$ $30.9 \mathrm{MJ} / \mathrm{kg}$; after 20,30 and 45 minutes of heating, the calorific values were $34.1 \mathrm{MJ} / \mathrm{kg}, \quad 34.1 \mathrm{MJ} / \mathrm{kg}$ and $34.0 \mathrm{MJ} / \mathrm{kg}$, respectively. The calorific value of dry pine wood was $20.0 \mathrm{MJ} / \mathrm{kg}$.

The calorific value of char resulting from pine wood was $20.5 \mathrm{MJ} / \mathrm{kg}$ after 5 minutes of heating; and the value of dry fir wood amounted to $19.5 \mathrm{MJ} / \mathrm{kg}$, with the difference of only $1.0 \mathrm{MJ} / \mathrm{kg}$, while for some species the difference in calorific values amounted to $6.5-7.2 \mathrm{MJ} / \mathrm{kg}$. After 10 minutes of heating, the calorific value of fir char was $29.8 \mathrm{MJ} / \mathrm{kg}$; after $20 \mathrm{~min}-33.5 \mathrm{MJ} / \mathrm{kg}$; after $30 \mathrm{~min}-33.6 \mathrm{MJ} / \mathrm{kg}$; after $45 \mathrm{~min}-33.6 \mathrm{MJ} / \mathrm{kg}$.

After 5 minutes of heating, the highest calorific value was of char resulting from pine wood $(26.5 \mathrm{MJ} / \mathrm{kg})$, the lowest was that of fir $(20.5 \mathrm{MJ} / \mathrm{kg})$, with the difference between the highest and the lowest values amounting to $6 \mathrm{MJ} / \mathrm{kg}$. After 10, 20, 30 and 45 minutes of heating, the differences between the lowest and the highest values were small: after $10 \mathrm{~min}-1.4 \mathrm{MJ} / \mathrm{kg}$, after $20 \mathrm{~min}-0.6 \mathrm{MJ} / \mathrm{kg}$, after $30 \mathrm{~min}-0.5 \mathrm{MJ} / \mathrm{kg}$, and after $45 \mathrm{~min}-0.4 \mathrm{MJ} / \mathrm{kg}$.

The calorific value of char resulting from different species of wood after they were heated for 20 minutes and longer (the average heating temperature reaching $\geq 780^{\circ} \mathrm{C}$ ) were within the range of $33.5 \mathrm{MJ} / \mathrm{kg}$ and $34.1 \mathrm{MJ} / \mathrm{kg}$. This small change in the calorific values at the temperature higher than $780{ }^{\circ} \mathrm{C}$ can be explained by the data obtained by another author (Demirbas 2001). According to Demirbas (2001), when carbonising fir wood to the temperature of $777^{\circ} \mathrm{C}$, the resulting char residue in the elemental composition is $91.2 \%$ of carbon, $1.5 \%$ of hydrogen, $4.0 \%$ of oxygen, $0.1 \%$ of nitrogen, and $3.1 \%$ of ash; and if heated to the temperature of $877{ }^{\circ} \mathrm{C}-92.1 \%$ of carbon, $1.2 \%$ of hydrogen, $3.3 \%$ of oxygen, $0.1 \%$ of nitrogen, and $3.3 \%$ of ash. The composition of fir wood before tests was: $51.9 \%$ of carbon, $6.1 \%$ of hydrogen, $40.9 \%$ of oxygen, $0.3 \%$ of nitrogen. If wood is heated at the temperature above $780{ }^{\circ} \mathrm{C}$, changes in the elemental composition of the resulting char residue are slight, therefore the differences between the calorific values are small and the calorific value depends namely on the amount of carbon, hydrogen and oxygen in the material. The theoretical calorific value of lignocellulosic materials is calculated according to the formula (7) (Demirbas et al. 1997):

$$
H H V=0.335(C)+1.423(H)-0.154(O),
$$

where: $\mathrm{HHV}$ - calorific value $(\mathrm{MJ} / \mathrm{kg}) ; \mathrm{C}, \mathrm{H}, \mathrm{O}$ - amount of elements (carbon, hydrogen, oxygen) in the material (\%).

The ratio of the calorific values for char resulting from different species of wood and dry wood are provided in Fig. 14. The ratio was calculated by dividing the calorific value of char resulting from wood after heating it for a definite period of time by the determined calorific value of the same species of dry wood.

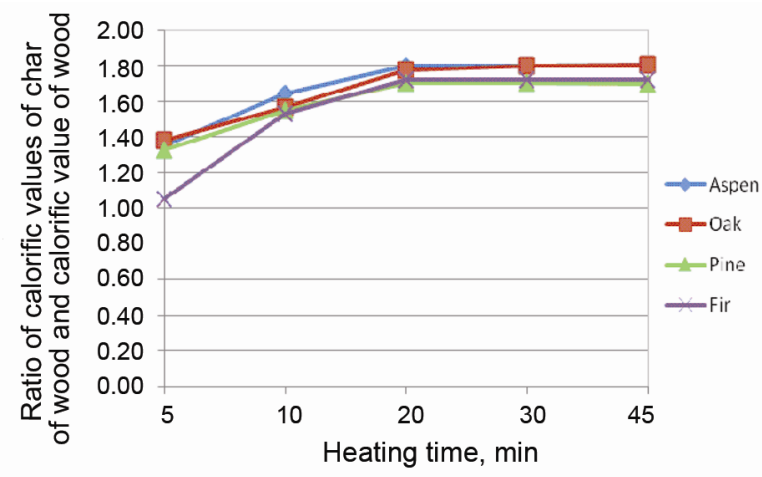

Fig. 14. Ratio of calorific values of char resulting from different species of wood and calorific value of wood

The smallest ratio of the calorific values is between char resulting from fir wood after heating it for 5 minutes and dry fir wood, namely -1.05 . The ratio between the calorific values of char resulting from other species of 
wood after heating for 5 minutes and dry wood is 1.33 1.38. The smallest ratio of the calorific values is between char resulting from wood after heating it for 10 minutes as well as that of fir wood -1.53 . The ratio between the calorific values of char resulting from other species of wood after heating for 10 minutes and dry wood is $1.55-1.64$.

If wood is heated for 20 minutes and longer, similarities between fir and pine as well as between oak and aspen, that is, between softwood and hardwood, emerge. The values of the calorific value ratios for fir char and wood become practically equal to the ratio values for pine. The same situation is between oak and aspen. The values of the calorific value ratios for hardwood char and wood are higher than that of softwood.

Using a calorimetric bomb method, it is possible to determine the amount of heat released by the completely burnt material. However, the amount of this heat is different from the heat, which would be emitted during a fire (Heskestad 2006; Heskestad, Delichatsios 1989). There are two wood burning mechanisms: 1) pyrolysing combustible vapours, which burn in the gaseous phase and 2) burning as a solid, at the surface (char burning); therefore during the burning process, different amount of heat is emitted during different stages. This can be confirmed by results obtained from the test on a $17 \mathrm{~mm}$ sample of the Western red cedar. It is clear that the effective heat of combustion is not a constant; it is roughly $12 \mathrm{MJ} / \mathrm{kg}$ for the first part of

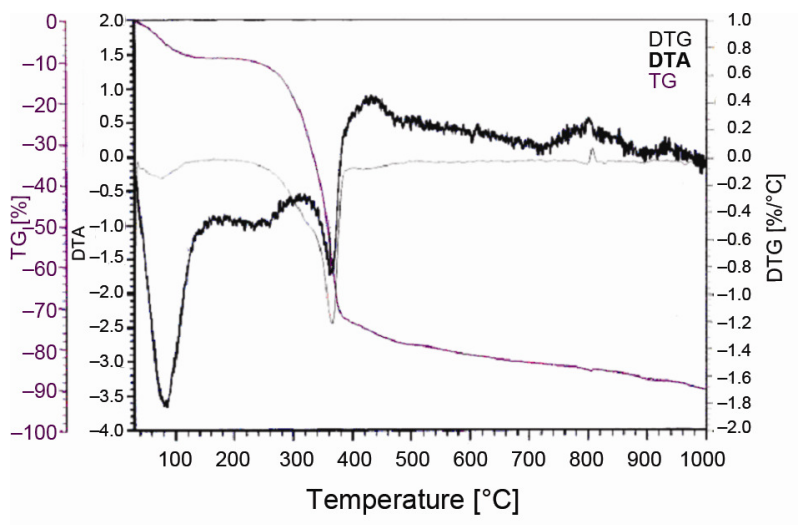

a)



b) the test, but increases to around $30 \mathrm{MJ} / \mathrm{kg}$ during the charring period at the end of the test (Babrauskas 2008).

For pine (Fig. $15 \mathrm{a}$ and b) and oak (Fig. $15 \mathrm{c}$ and d), thermogravimetric research was carried out. Thermogravimetric research was conducted in different gaseous media: nitrogen (Fig. $15 \mathrm{a}$ and c) and air (Fig. $15 \mathrm{~b}$ and d).

Pyrolysis of pine took place in stages in the nitrogen environment (Fig. 15 a). The endo-effect in the DTA curve $\left(\min 85.4{ }^{\circ} \mathrm{C}\right)$ can be interpreted by elimination of moisture (water) present in wood. Here, the loss of mass was $5.6 \%$. The exo-effect becomes apparent in the first stage at a temperature of $85-230^{\circ} \mathrm{C}\left(\max \sim 170{ }^{\circ} \mathrm{C}\right)$. Then, reactions of hemicellulose pyrolysis and oxidation take place. The loss of mass at this stage was $\sim 7 \%$.

The second exothermal effect during pyrolysis became apparent at the temperature of $230-361{ }^{\circ} \mathrm{C}$ (max $\sim 300^{\circ} \mathrm{C}$ ). At this stage, the mass is lost suddenly and the total loss amounts to $\sim 49 \%$ (DTG curve). This means that the largest amount of volatile gas forms here, and decomposition and combustion of cellulose prevails.

The third exothermal effect - and at the same time the stage of pyrolysis - took place when the temperature exceeded $361.2^{\circ} \mathrm{C}$ and was over at approximately $710{ }^{\circ} \mathrm{C}$. Its maximum was at $\sim 430{ }^{\circ} \mathrm{C}$. The process progressed at a lower speed compared to the second stage and here gasification and oxidation reactions of lignin prevailed. The total loss in this stage amounted to $\sim 20 \%$.

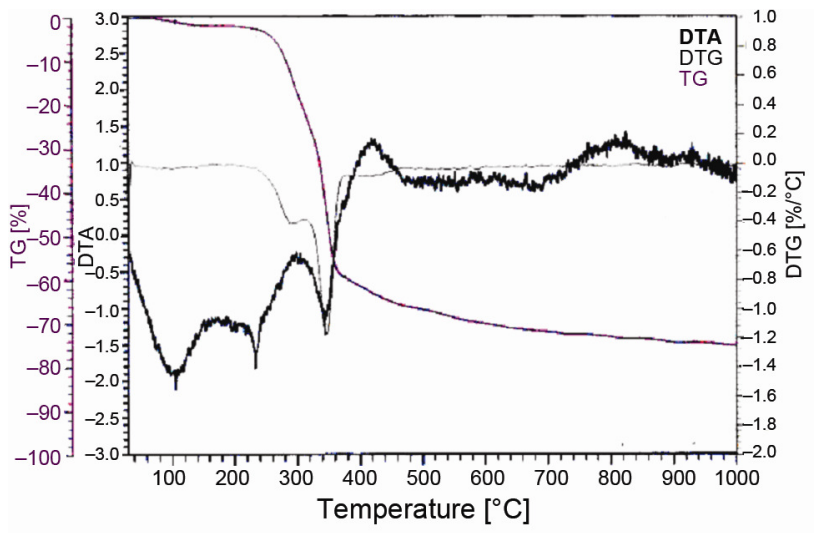

c)

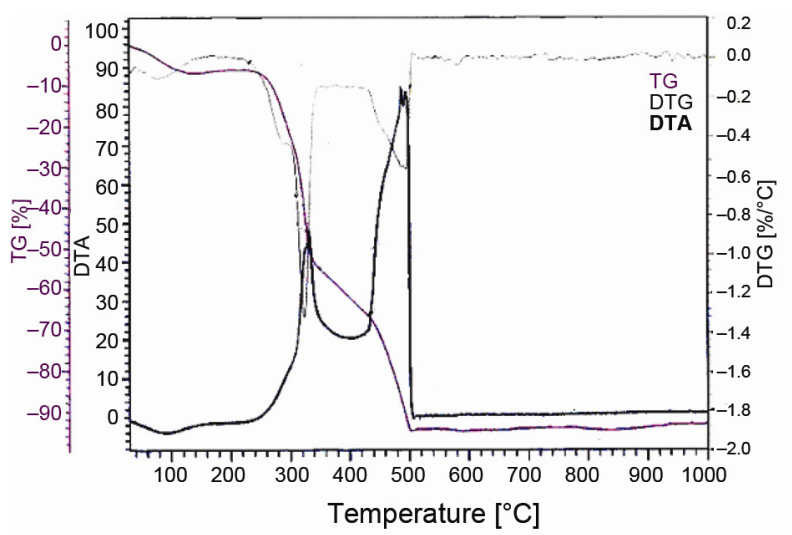

d)

Fig. 15. Curves of thermogravimetric analysis for oak and pine wood ( $\mathrm{a}$ - pine, nitrogen medium; $\mathrm{b}$ - pine, air medium; $\mathrm{c}$ - oak, nitrogen medium; d-oak, air medium) 
Later, two more exo-effects became apparent with maximums at $\sim 810^{\circ} \mathrm{C}$ and $\sim 930^{\circ} \mathrm{C}$. This could be interpreted by combustion of char itself and its monoxide. The loss in these stages was $\sim 7 \%$. The total loss of mass amounted to $\sim 89 \%$.

It must be pointed out that all combustion reactions took place due to oxygen present in the chemical composition of wood and its capillaries because the research was carried out in the nitrogen environment.

Gasification and combustion of pine in the air environment also took place in stages (Fig. $15 \mathrm{~b}$ ). The endoeffect in the DTA curve $\left(\min 84^{\circ} \mathrm{C}\right)$ can be interpreted by elimination of moisture present in wood. The loss of mass amounted to $\sim 5 \%$. The first exothermal effect during pyrolysis and oxidation of hemicellulose became apparent at the temperature of $84-405{ }^{\circ} \mathrm{C}$ (max $\sim 330.6{ }^{\circ} \mathrm{C}$ ). It should be emphasized that in fact the course of the DTA curve was also different at the first stage compared to the one in the nitrogen medium. The total loss of mass at this stage was $\sim 65 \%$ of the total mass of the sample. That was the most intense loss of mass, which significantly differed from the results of the tests in nitrogen gas.

The second exothermal effect during pyrolysis and combustion of cellulose became apparent at the temperature of $405-470{ }^{\circ} \mathrm{C}\left(\max \sim 456.9^{\circ} \mathrm{C}\right)$. Mass was lost rather quickly (DTG curve) and the total loss of mass amounted to $\sim 18 \%$.

The third exothermal effect during decomposition and combustion reactions of lignin became apparent at the temperature of $470-500{ }^{\circ} \mathrm{C}\left(\max \sim 473.9^{\circ} \mathrm{C}\right)$. The total loss of mass at this stage amounted to $\sim 6 \%$.

The character of curves for the latter two stages differed significantly from the ones in nitrogen medium. Moreover, the results showed that in the temperature range, practically no processes took place. The total loss of mass amounted to $\sim 94 \%$.

Gasification and combustion of oak in the nitrogen environment also takes place in stages (Fig. 15 c). The endo-effect in the DTA curve $\left(\min 105.2^{\circ} \mathrm{C}\right)$ can be interpreted by elimination of moisture present in wood, which makes $1.0 \%$ of the total mass. The exo-effect in the first stage became apparent at the temperature of $105.2-232.8^{\circ} \mathrm{C}\left(\max \sim 180^{\circ} \mathrm{C}\right)$. Pyrolysis and oxidation reactions of hemicelluloses also took place at this stage. The total loss of mass at this stage amounted to $\sim 1.5 \%$.

The second stage of pyrolysis took place at the temperature of $232.8-343.8^{\circ} \mathrm{C}$. Its maximum was $\sim 300^{\circ} \mathrm{C}$. At this stage, mass was lost at high speed and its loss amounted to $\sim 44 \%$. The largest amount of volatile gas formed at this stage, and decomposition of cellulose and combustion of its pyrolysis products prevailed.

The third exothermal effect during pyrolysis and oxidation became apparent at the temperature of 232.8 $695^{\circ} \mathrm{C}$ (max $\sim 420^{\circ} \mathrm{C}$ ). The total loss of mass at this stage amounted to $\sim 25 \%$. Reactions of lignin decomposition and combustion of its products prevailed.

Later, two more exo-effects became apparent with maximums at $\sim 827^{\circ} \mathrm{C}$ and $\sim 928^{\circ} \mathrm{C}$. This could be interpreted by combustion of char itself and its monoxide. The loss in these stages was $\sim 4 \%$. The total loss of mass amounted to $\sim 75 \%$.

Decomposition of oak in the air environment also took place in stages (Fig. 15 d). The endo-effect in the DTA curve $\left(\min 96^{\circ} \mathrm{C}\right)$ can also be interpreted by elimination of moisture present in wood. The loss of mass amounted to $\sim 5 \%$. The exo-effect in the first stage became apparent at the temperature of $\sim 96-400{ }^{\circ} \mathrm{C}$ (max $\sim 330.9^{\circ} \mathrm{C}$ ). Pyrolysis and oxidation reactions of hemicelluloses also took place at this stage. Mass was lost at a very high speed at this stage and its total loss amounted to $\sim 44 \%$.

The second stage of pyrolysis of cellulose and oxidation of its products took place at the temperature of $\sim 400-4900^{\circ} \mathrm{C}$. The maximum of the exo-effect was $486.7^{\circ} \mathrm{C}$. The total loss of mass in this stage amounted to $\sim 23 \%$.

The third stage of pyrolysis took place at the temperature of $490-505^{\circ} \mathrm{C}$. The maximum of the exo-effect was $493.3{ }^{\circ} \mathrm{C}$. The total loss of mass at this stage amounted to $\sim 23 \%$. Reactions of lignin destruction and combustion prevailed.

The total loss of mass amounted to $\sim 95 \%$. Moreover, the results showed that in the temperature range of $505-1000{ }^{\circ} \mathrm{C}$, practically no processes took place.

As it can be seen from the thermograms presented in Fig. 15, the results of thermogravimetric analysis in different environment for oak and pine are essentially different but in terms of nature, they are similar when research is carried out in the same gas medium.

Pyrolysis and oxidation of wood in nitrogen environment starts and is more intense at lower temperatures. These processes take place due to presence of oxygen in wood.

When tests were performed in air environment, pyrolysis and oxidation of individual components of wood started and were more intense at higher temperatures.

\section{Conclusions}

1. The charring rates of wood increase as the heating time increases, with the exception of oak wood, the charring rate of which after 10 minutes of heating is smaller that after 5 minutes of heating. From among the tested species of wood (fir, pine, oak and aspen) the smallest charring rate was for oak, the largest - after 10 and 20 minutes of heating - for pine, after 30 and 45 minutes - for aspen, after 5 minutes of heating the charring rate for pine and aspen was the same.

2. The largest value of the correlation coefficient $(\mathrm{R}=0.9597)$ was obtained when predicting the charring rate for aspen and the smallest value $(\mathrm{R}=0.9240)$ was obtained when predicting the charring rate for pine. The values of the obtained correlation coefficients in the experimental equations are $0.9240-0.9597$, which means that there is an obviously close interdependence of parameters.

3. The calorific values of char residue, irrespective of the time of wood heating, are higher than those of wood from which char residue has been obtained. The calorific value of dry wood is $18.7-20.0 \mathrm{MJ} / \mathrm{kg}$ and the 
calorific value of char residue after 5 minutes of heating is $20.5-26.5 \mathrm{MJ} / \mathrm{kg}$.

4. The calorific values of resulting char residue increase rapidly until 20 minutes of heating. After 5 minutes of heating the calorific value reaches 20.5$26.5 \mathrm{MJ} / \mathrm{kg}$ and after 20 minutes - 33.5-34.1 MJ/kg. Later, after 30 and 45 minutes of heating, the calorific values change insignificantly. Then the difference between the largest and the smallest value is about $0.6 \mathrm{MJ} / \mathrm{kg}$

5. The results of the thermogravimetric analysis in different environment for oak and pine are essentially different. However, in terms of nature they are rather similar when research is carried out in the same gas medium.

6. In nitrogen environment pyrolysis and oxidation of individual species of wood due oxygen present in wood starts and is more intense in lower temperature range, and for three components it continues even to the temperature of $\sim 700{ }^{\circ} \mathrm{C}$. Later, two more exo-effects become apparent with maximums at $\sim 810-827^{\circ} \mathrm{C}$ and $\sim 928-930^{\circ} \mathrm{C}$. This could be interpreted by combustion of char itself and its monoxide, which is confirmed by large residue: $11 \%$ in case of pine and $25 \%$ in case of oak.

7. In air environment, pyrolysis and oxidation of individual components of wood starts and is more intense in the range of higher temperatures, however ends having in fact reached $\sim 500{ }^{\circ} \mathrm{C}$ and later on no processes take place. Amount of residue is small: $6 \%$ in case of pine and $5 \%$ in case of oak.

\section{References}

Babrauskas, V. 2005. Charring rate of wood as a tool for fire investigations, Fire Safety Journal 40(6): 528-554. http://dx.doi.org/10.1016/j.firesaf.2005.05.006

Babrauskas, V. 2008. Heat Release Rates. The SFPE Handbook of Fire Protection Engineering. 4th Ed. National Fire Protection Assotiation, Quincy, MA. 628 p.

Bednarek, Z.; Griškevičius, M.; Šaučiuvenas, G. 2009. Tensile, compressive and flexural strength reduction of timber in fire, Engineering Structures and Technologies 1(3): 148156. http://dx.doi.org/10.3846/skt.2009.18

Demirbas, A. 2001. Carbonization ranking of selected biomass for charcoal, liquid and gaseous products, Energy Conversion and Management 42(10): 1229-1238. http://dx.doi.org/10.1016/S0196-8904(00)00110-2

Demirbas, A; Gullu, D.; Çaglar, A.; Akdeniz, F. 1997. Estimation of calorific values of fuels from lignocellulosics, Energy Sources 19(8): 765-770.

http://dx.doi.org/10.1080/00908319708908888

Drysdale, D. 1998. An introduction to Fire Dynamics. 2nd ed. John Willey and Sons. $447 \mathrm{p}$.

Hagen, M.; Hereid, J.; Delichatsios, M. A.; Zhang, J.; Bakirtzis, D. 2009. Flammability assessment of fire-retarded Nordic Spruce wood using thermogravimetric analyses and conecalorimetry, Fire Safety Journal 44(8): 10531066. http://dx.doi.org/10.1016/j.firesaf.2009.07.004

Helsen, L.; Van den Bulck, E.; Mullens, S.; Mullens, J. 1999. Low-temperature pyrolysis of CCA-treated wood: thermogravimetric analysis, Journal of Analytical and Applied Pyrolysis 52(1): 65-86.

http://dx.doi.org/10.1016/S0165-2370(99)00034-0
Heskestad, G. 2006. Heat of combustion in spreading wood crib fires with application to ceiling jets, Fire Safety Journal 41(5): 343-348.

http://dx.doi.org/10.1016/j.firesaf.2006.01.008

Heskestad, G.; Delichatsios, M. A. 1989. Update: The initial convective flow in fire, Fire Safety Journal 15(6): 471475. http://dx.doi.org/10.1016/0379-7112(89)90017-9

Jakimavičius, Č. 2003. Medienotyra [Timber study]. Kaunas: Technologija. $271 \mathrm{p}$.

Jaskolowski, W. 2001. Szybkosc zweglania i generacji ciepla podczas spalania drewna zabezpieczonego przeciwogniowo [Rate of heat generation and formation of char on the samples surface during burning wood which is protected from fire]. Poznan, Poland. 87 p.

Jefimovas, A. 2011. Medienos degimo ir anglejjimo ypatumai [Peculiarities of timber combustion and charring], in 14-oji Lietuvos jaunuju mokslininku konferencija „,Mokslas - Lietuvos ateitis", sekcija "Statyba" $\left[14^{\text {th }}\right.$ Conference of Lithuanian young scientists "Science - Future of Lithuania, Section "Construction], Vilnius, Lithuania, 2011. $5 \mathrm{p}$.

Koufopanos, C. A.; Lucchesi, A.; Mashio, G. 1989. Kinetic modelling of the pyrolisis of biomass and biomass component, The Canadian Journal of Chemical Engineering 67(1): 75-84. http://dx.doi.org/10.1002/cjce.5450670111

Lipinskas, D. 2006. Gaisro kilimo vietos nustatymas pagal mediniu konstrukciju apanglejima [Prediction of fire origin location to wood materials sharring]. PhD Thesis. Vilnius: Vilnius Gediminas Technical University. 128 p.

Lipinskas, D.; Mačiulaitis, R. 2005. Further opportunities for development of the method for fire origin prognosis, Journal of Civil Engineering and Management 11(4): 299-307.

http://dx.doi.org/10.1080/13923730.2005.9636361

LST EN ISO 1716:2010 Gaminiu reakcijos i ugni bandymai. Degimo šilumos (šilumingumo) nustatymas [Reaction to fire tests for products - Determination of the gross heat of combustion (calorific value)]. European committee for standardization, Brussels. $42 \mathrm{p}$.

LST EN 1363-1:2000 Atsparumo ugniai bandymai. 1 dalis. Bendrieji reikalavimai [Fire resistance tests - Part 1: General requirements]. European committee for standardization, Brussels. 29 p.

LST EN 13501-1:2007 Statybos gaminiu ir statinio elementu klasifikavimas pagal atsparuma ugniai. 1 dalis. Klasifikavimas pagal atsako i ugni bandymu duomenis [Fire classification of construction products and building elements - Part 1: Classification using data from reaction to fire tests]. European committee for standardization, Brussels. 53 p.

LST EN 13238:2010 Statybiniu gaminiu reakcijos i ugni bandymai. Kondicionavimo procedūros ir bendrosios pagrindu atrankos taisykles [Reaction to fire tests for building products - Conditioning procedures and general rules for selection of substrates]. European committee for standardization, Brussels. $11 \mathrm{p}$.

LST EN 1995-1-2:2005 Eurokodas 5. Mediniu konstrukciju projektavimas. 1-2 dalis. Bendrosios nuostatos. Konstrukciju elgsenos ugnyje skaičiavimas. [Eurocode 5: Design of timber structures - Part 1-2: General - Structural fire design]. European committee for standardization, Brussels. 73 p.

Lukošius, K. 2004. Naujas vienpusis konstrukciju kaitinimo metodas ir jo taikymas prognozuojant atitvariniu konstrukciju atsparuma ugniai [New one side heating method 
for structures and its application for prediction of fire resistance of structures with separation function]. PhD Thesis. Vilnius: Vilnius Gediminas Technical University. $100 \mathrm{p}$.

Otero, M.; Gómez, X.; García, A. I.; Morán, A. 2007. Effects of sewage sludge blending on the coal combustion: A thermogravimetric assessment, Chemosphere 69(11): 17401750.

http://dx.doi.org/10.1016/j.chemosphere.2007.05.077

Roberts, A. F. 1970. A review of kinetic data for the pyrolysis of wood and related substances, Combustion and Flame 14(2): 261-272.

http://dx.doi.org/10.1016/S0010-2180(70)80037-2

Šniuolis, R. 2004. Inžinerinès medžiagos [Engineering Materials]. Šauliai: Lucilijus. 255 p.

Tan, F. T.; Ma, X. Q.; Feng, C. 2011. Investigation on combustion of fire retardant board under different $\mathrm{N}_{2}-\mathrm{O}_{2}$ mixture gas atmospheres by using thermogravimetric analysis, Construction and Building Materials 25(4): 2076-2084. http://dx.doi.org/10.1016/j.conbuildmat.2010.11.036
Taubkin, S. I. 1999. Pozhar i vzryv, osobennosti ikh ekspertizy. Moskva: VNIIPO. $600 \mathrm{~s}$.

Turner, I.; Rousset, P.; Rémond, R.; Perré, P. 2010. An experimental and theoretical investigation of the thermal treatment of wood (Fagus sylvatica L.) in the range 200$260^{\circ} \mathrm{C}$, International Journal of Heat and Mass Transfer 53(4): 715-725.

http://dx.doi.org/10.1016/j.ijheatmasstransfer.2009.10.020

Yorulmaz, S. Y.; Atimtay, A. T. 2009. Investigation of combustion kinetics of treated and untreated waste wood samples with thermogravimetric analysis, Fuel Processing Technology 90(7): 939-946.

http://dx.doi.org/10.1016/j.fuproc.2009.02.010

Zhaosheng, Y.; Xiaoqian, M.; Ao, L. 2009. Thermogravimetric analysis of rice and wheat straw catalytic combustion in air- and oxygen-enriched atmospheres, Energy Conversion and Management 50(3): 561-566.

http://dx.doi.org/10.1016/j.enconman.2008.10.022

Romualdas MAČIULAITIS. Prof., Dr Habil of Technological Sciences at the Department of Building Materials, Vilnius Gediminas Technical University (VGTU). Research interests: development of building materials and analysis of their characteristics.

Andrejus JEFIMOVAS. A PhD student at the Department of Building Materials, Vilnius Gediminas Technical University (VGTU). Research interests: research of timber charring.

Povilas ZDANEVIČIUS. A PG student at the Department of Building Materials, Vilnius Gediminas Technical University (VGTU). Research interests: research of timber charring. 